\title{
Penggunaan Bahan Penstabil dalam Kitar Semula Sejuk Setempat Turapan Jalan Raya Boleh Lentur
}

(The Use of Stabilisation Materials in Cold-in Place Recycling of Flexible Pavement)

\author{
Asmah Hamim \& Nur Izzi. Md. Yusoff*
}

ABSTRAK

Kajian ini telah dijalankan untuk menilai keberkesanan penggunaan wasap silika, abu sekam padi dan batu kapur sebagai bahan penstabil dalam kitar semula sejuk setempat turapan jalan raya boleh lentur. Satu sampel campuran kitar semula sejuk setempat terdiri daripada 75\% turapan asfalt kitar semula yang diambil di tapak, 25\% batuan hancur dan $5.05 \%$ air. Campuran asfalt yang mengandungi 1.5\% simen (daripada jumlah berat sampel) telah dijadikan sebagai sampel piawai. Manakala sampel-sampel ujikaji masing-masing dicampurkan dengan wasap silika, abu sekam padi dan batu kapur pada kadar 1, 3, 5, 7 dan 9\%. Lima ujikaji yang berbeza; iaitu ujikaji pemadatan menggunakan kaedah tukul penggetar, ujikaji Kestabilan dan Aliran Marshall, ujikaji mampatan tak terkurung, ujikaji modulus kekuatan tegangan tak terus dan ujikaji rayapan statik telah dijalankan. Didapati bahawa kesemua bahan penstabil menunjukkan keputusan yang tidak sejajar berbanding dengan sampel yang dicampurkan dengan 1.5\% simen. Penggunaan campuran abu sekam padi sebanyak 7\% didapati mempunyai potensi sebagai bahan penstabil kerana mempunyai kekuatan dan daya menahan beban yang lebih tinggi serta kerintangan terhadap rayapan yang lebih baik berbanding dengan campuran wasap silika dan batu kapur. Keputusan ujikaji juga mendapati bahawa kandungan optimum bagi wasap silika dan batu kapur masingmasing ialah sebanyak 7\% dan 3\% diperlukan untuk menghasilkan satu campuran kitar semula sejuk setempat yang baik.

Kata kunci: kitar semula sejuk setempat; simen; wasap silika; abu sekam padi dan batu kapur

\section{ABSTRACT}

This study was conducted to investigate the effectiveness of using silica fume, rice husk ash and lime as stabilisation materials in the cold-in-place recycling of flexible pavement. The cold-in-place recycling sample consists of $75 \%$ of recycling asphalt pavement taken from the site, $25 \%$ of crushed run and 5.05\% of water. Asphalt mixture added with $1.5 \%$ cement (by total weight of a sample) was used as a control sample. Meanwhile silica fume, rice husk and limestone were added to samples at different percentages of 1, 3, 5, 7 and 9\%. Five different tests; namely compaction test using vibrating hammer, Marshall Stability and Flow tests, unconfined strength test, indirect tensile modulus test and static creep test were conducted. It was found that all the stabilisation materials show inconsistent results compared to the $1.5 \%$ cement mixture. However, the use of 7\% of rice husk shows good potential as a stabilisation material because of its strength, better withstand for higher loads and higher creep resistance compared to the silica fume and limestone mixtures. The results also showed that the optimum content of silica fume and limestone are 7\% and 3\% respectively to produce good cold-in-place recycling mixture.

Keywords: Cold-in-place recycling; cement; silica fume; rice husk and limestone

\section{PENGENALAN}

Sejak beberapa dekad yang lalu pertambahan bilangan trafik di atas jalan raya, pengurangan dana peruntukan dan keperluan untuk menyediakan sistem jalan raya yang selamat, efisien dan kos yang efektif telah mendorong peningkatan kepada kerja pembaikan turapan jalan raya sedia ada. Penggunaan kaedah kitar semula dan guna semula turapan jalan raya telah memperlihatkan perkembangan yang dramatik kerana kaedah ini bersifat mesra alam dalam kerja penambah-baikan turapan jalan raya. Kaedah ini juga didapati memenuhi semua kehendak sosial kerana ia selamat, efisien dan pada masa yang sama ia akan mengurangkan kesan kepada alam sekitar dan pembakaran bahan api jika dibandingkan dengan kaedah pembaikan yang sedia ada (Asphalt Recycling and Reclaming Association 2001). 
Dalam kajian ini, keberkesanan penggunaan bahan penstabil dalam kaedah kitar semula sejuk setempat bagi kerja penyelenggaraan jalan raya dikaji. Skop kajian tertumpu kepada turapan boleh lentur iaitu turapan berasfalt yang digunakan secara meluas di Malaysia. Proses yang terlibat ialah mengguna pakai semula turapan sedia ada, menyuntik bahan penstabil ke dalamnya, menghampar dan kemudiannya memadat turapan tersebut. Tiga bahan penstabil yang digunakan iaitu wasap silika, abu sekam padi dan batu kapur adalah merupakan bahan buangan daripada aktiviti pemprosesan. Ujikaji-ujikaji di makmal telah dilakukan dan keputusan yang diperolehi dibandingkan dengan sampel kawalan. Ini bertujuan untuk menentukan sama ada bahan-bahan buangan ini mampu untuk mengganti atau menyamai peratusan simen untuk meningkatkan kekuatan turapan. Peratusan wasap silika, abu sekam padi dan batu kapur yang digunakan adalah di antara 1, 3, 5, 7 dan 9\%. Sampel yang megandungi 1.5\% campuran simen pula digunakan sebagai sampel piawai.

\section{ULASAN KEPUSTAKAAN}

Jalan raya memainkan peranan penting dalam aktiviti perdagangan dan sistem pengangkutan di seluruh dunia. Sejajar dengan kepentingan tersebut, Malaysia adalah negara yang tidak terkecuali mengalami perkembangan pesat dalam pembangunan sistem infrastruktur turapan jalan raya. Sehingga kini, dianggarkan panjang jalan raya di Malaysia melebihi $80,300 \mathrm{~km}$. Jalan-jalan ini terbahagi kepada tiga iaitu lebuhraya bertol $(1,700 \mathrm{~km})$, jalan persekutuan $(17,500 \mathrm{~km})$ dan jalan negeri $(61,100 \mathrm{~km})$. Kebanyakan jalan persekutuan di Malaysia diturap dengan asfalt yang mana ia mempunyai jangka hayat di antara 10-15 tahun untuk menampung beban trafik (Kordi et al. 2010).

Piawaian reka bentuk jalan raya baru adalah berdasarkan jangkaan bahawa penyelenggaraan perlu dijalankan secara berkala untuk menangani kemerosotan yang tidak dapat dielakkan disebabkan oleh beban trafik, kesan iklim dan sebagainya. Oleh itu, penyelenggaraan jalan raya adalah satu keperluan asas dan perlu dirancang, direka dan dilaksanakan dengan baik untuk menyediakan perkhidmatan yang terbaik kepada pengguna jalan raya selain tidak melanggar undang-undang yang ditetapkan oleh pihak kerajaan (Oliver 2002). Kaedah penyelenggaraan turapan jalan raya yang terbaik perlu dipilih bagi mengekalkan keselamatan dan keselesaan pengguna jalan raya.

Kaedah kitar semula turapan jalan raya adalah salah satu penyelesaian terbaik untuk membaiki jalan raya yang rosak kerana menjimatkan kos, mengurangkan penggunaan bahan-bahan baru, mesra alam, dan memulihara turapan sedia ada. Kaedah ini melibatkan penggunaan semula turapan jalan raya yang rosak dengan menyuntik bahan penstabil yang murah dan senang diperolehi untuk meningkatkan kekuatan turapan. Masalah pembaziran dan kewangan mungkin dapat dikurangkan apabila kaedah kitar semula turapan dapat dipraktikkan secara meluas di negara kita. Menurut the Asphalt Recycling and Reclaming Association (ARRA), terdapat empat jenis kaedah kitar semula turapan jalan raya iaitu kitar semula panas setempat, kitar semula campuran panas, kitar semula sejuk setempat dan pembaikan kedalaman penuh (Asphalt Recycling and Reclaming Association 2001).

KITAR SEMULA SEJUK SETEMPAT

Kitar semula sejuk setempat adalah satu teknik penyelenggaraan turapan asfalt yang memproses semula turapan sedia ada. Proses yang terlibat ialah mengisar sejuk campuran dan menambah bitumen emulsi serta agregat (jika diperlukan) ke dalam campuran turapan sedia ada tersebut. Semua kerja dilaksanakan di tapak dan pengangkutan untuk mengangkut bahan kecuali apabila bahan tambahan digunakan adalah tidak diperlukan. Kedalaman turapan yang terlibat biasanya adalah di antara 75-100 mm. Proses ini juga kenali sebagai kitar semula separuh kedalaman kerana lapisan asas dan kebanyakan bahan bitumen akan dikekalkan. Selepas proses penghamparan dan pengawetan selesai, lapisan turapan baru akan dilapisi dengan lapisan penghausan (Cross et al. 2010).

Antara kelebihan proses kitar semula sejuk setempat ialah menggunakan majoriti lapisan turapan sedia ada, meminimumkan pengimportan bahan-bahan dari kuari, mengurangkan pengangkutan dan penggunaan tenaga. Selain itu proses ini akan menghasilkan turapan baru yang berkualiti, mengekalkan integriti struktur turapan, meminimumkan gangguan pada lapisan subgred, mengurangkan tempoh pembinaan, selamat dan kos yang efektif (Wirtgen 2004).

Di Malaysia, terdapat tiga jenis kaedah kitar semula sejuk setempat yang menggunakan bahan penstabil yang berlainan. Bahan-bahan penstabil yang digunakan mempunyai kelebihan masing-masing dan akan dipilih berdasarkan kepada faktor harga, keadaan pasaran, ciriciri bahan dan polisi tertentu. Kaedah kitar semula sejuk setempat yang biasa diaplikasikan di negara kita ialah kitar semula sejuk setempat menggunakan simen, kitar semula sejuk setempat menggunakan asfalt emulsi dan kitar semula sejuk setempat menggunakan asfalt buih (Road Engineering Association of Malaysia 2005). Jadual 1-3 menunjukkan spesifikasi yang telah ditetapkan bagi keputusan ujikaji makmal yang dilakukan untuk ketiga-tiga bahan penstabil tersebut dalam kitar semula sejuk setempat.

\section{BAHAN-BAHAN BUANGAN}

Industri pembinaan jalan raya mempunyai sejarah yang tersendiri tentang penggunaan bahan kitar semula dalam pembinaan jalan raya. Sehingga kini, industri telah menggunakan bahan-bahan buangan seperti produk buangan daripada penyulingan minyak dan abu terbang dalam konkrit simen Portland untuk meningkatkan kualiti dan ketahanan infrastruktur jalan raya. Antara bahanbahan buangan lain yang digunakan ialah serpihan tayar, kaca, plastik, abu dari hasil penunuan bahan sisa pepejal perbandaran, relau bagas berbutir, sisa sulfat, sisa daripada bengkel melebur kaca atau logam, sisa perlombongan dan sebagainya (Federal Highway Administration 1993). 
JADUAL 1. Spesifikasi bagi simen dalam kitar semula sejuk setempat

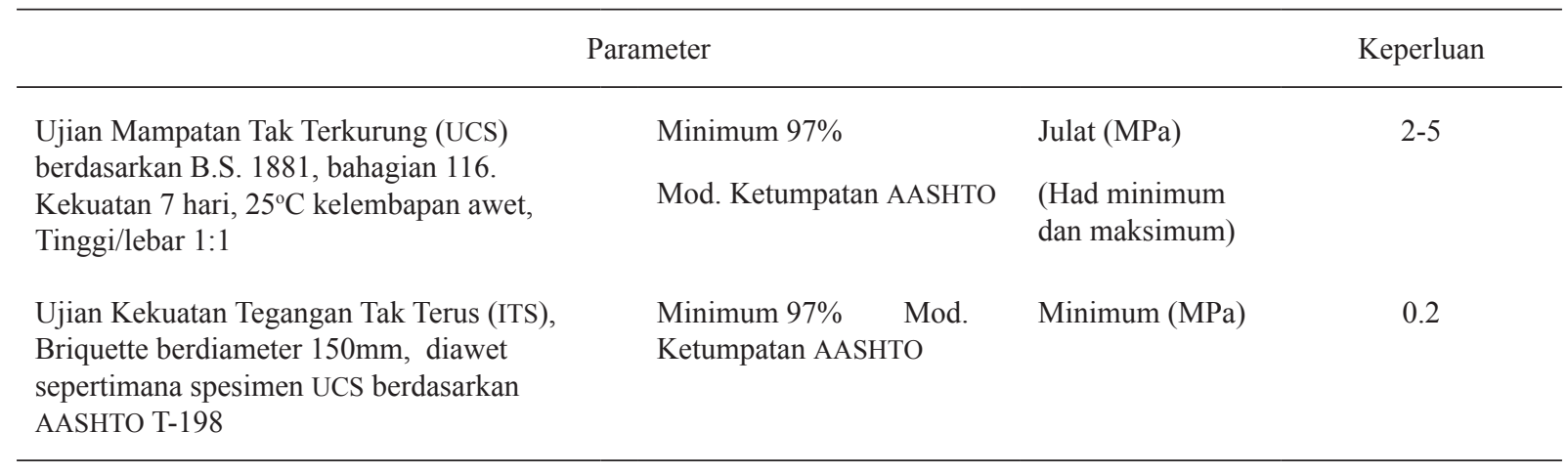

Kandungan Maksimum Simen Mengikut Berat

$5 \%$

Untuk tujuan rekabentuk struktur turapan menggunakan kaedah kompenan analisis, pekali interim $=0.45$ boleh digunakan untuk kitar semula sejuk setempat menggunakan simen.

Sumber: REAM - SP 1/2005

JADUAL 2. Spesifikasi bagi bitumen emulsi dalam kitar semula sejuk setempat

\begin{tabular}{llc}
\hline \multicolumn{1}{c}{ Parameter } & \multicolumn{1}{c}{$\begin{array}{c}\text { Kekuatan } \\
\text { Minimum (MPa) }\end{array}$} \\
\hline $\begin{array}{l}\text { Ujian Mampatan Tak Terkurung (UCS) berdasarkan B.S. 1881, } \\
\text { bahagian 116. Kekuatan 7 hari, 25C kelembapan awet, Tinggi/ } \\
\text { lebar 1:1 }\end{array}$ & $\begin{array}{l}\text { Minimum 97\% } \% \\
\text { Mod. Ketumpatan AASHTO }\end{array}$ \\
$\begin{array}{l}\text { Ujian Kekuatan Tegangan Tak Terus (ITS), Briquette berdiameter } \\
\text { 100mm, diawet pada suhu } 40^{\circ} \mathrm{C} \text { untuk 72 jam berdasarkan Marshall (75 } \\
\text { AASHTO T-198 }\end{array}$ & 0.2 \\
$\begin{array}{l}\text { Ujian Kekuatan Tegangan Tak Terus (ITS), Briquette yang diawet } \\
\text { direndam selama 24 jam berdasarkan AASHTO T-198 }\end{array}$ & $\begin{array}{l}\text { Pemadatan Marshall (75 } \\
\text { hentakan per sisi) }\end{array}$ & 0.15 \\
Minimum Kekuatan Tegangan & & $75 \%$ \\
\hline Maksimum Penambahan Kandungan Simen Mengikut Berat & & $2 \%$ \\
\hline
\end{tabular}

Untuk tujuan rekabentuk struktur turapan menggunakan kaedah kompenan analisis, pekali interim $=0.70$ boleh digunakan untuk kitar semula sejuk setempat menggunakan bitumen emulsi.

Sumber: REAM - SP 1/2005

JADUAL 3. Spesifikasi bagi bitumen buih dalam kitar semula sejuk setempat

\begin{tabular}{cc}
\hline Parameter & Kekuatan \\
Minimum (MPa)
\end{tabular}

Ujian Mampatan Tak Terkurung (UCS) berdasarkan B.S. 1881, bahagian 116 . Kekuatan 7 hari, $25^{\circ} \mathrm{C}$ kelembapan awet, Tinggi/lebar $1: 1$

Minimum 97\%

Ujian Kekuatan Tegangan Tak Terus (ITS), Briquette berdiameter $100 \mathrm{~mm}$, diawet pada suhu $40^{\circ} \mathrm{C}$ untuk 72 jam berdasarkan AASHTO T-198

Ujian Kekuatan Tegangan Tak Terus (ITS), Briquette yang diawet direndam selama 24 jam berdasarkan AASHTO T-198

Mod. Ketumpatan AASHTO

Pemadatan Marshall (75 hentakan per sisi)

Pemadatan Marshall (75

Minimum Kekuatan Tegangan

Untuk tujuan rekabentuk struktur turapan menggunakan kaedah kompenan analisis, pekali interim $=0.65$ boleh digunakan untuk kitar semula sejuk setempat menggunakan bitumen buih.

Sumber: REAM - SP 1/2005 
WASAP SILIKA

Wasap silika yang dikenali sebagai mikrosilika atau abu silika dihasilkan daripada pemprosesan aloi silikon atau aloi ferrosilikon. Wasap silika mempunyai kandungan silika dioksida yang tinggi (85-97\%). Ia terdiri daripada zarah-zarah silika berkaca berbentuk sfera yang terlalu halus. Dianggarkan sebanyak 800,000 tan/tahun wasap silika telah dihasilkan di negara-negara Barat. Di Mesir contohnya, penghasilan wasap silika sebagai bahan sampingan ialah lebih daripada 12,000 tan/tahun (Hamim 2007). Wasap silika adalah partikel-partikel yang sangat halus dengan lebih 95\% partikel-partikelnya bersaiz kurang daripada $0.1 \mu \mathrm{m}$.

Wasap silika juga dikenali sebagai campuran berpozzolanik yang mempunyai kesan efektif dalam meningkatkan sifat mekanikal sesuatu campuran. Penggunaan wasap silika yang dicampurkan bersama dengan bahan superplastik didapati lebih mudah untuk memperolehi nilai kekuatan mampatan sebanyak 100-150 MPa di dalam makmal. Pertambahan wasap silika ke dalam campuran konkrit pula akan meningkatkan ketahanan campuran tersebut kerana pengurangan ketertelapan, penapisan liang struktur, pengurangan dalam penyebaran ion-ion berbahaya dan pengurangan kandungan kalsium hidroksida yang akan menyebabkan kebolehrintangan terhadap serangan sulfat. Peningkatan ketahanan campuran konkrit berwasap silika tersebut juga akan meningkatkan kebolehupayaannya dalam melindungi besi tetulang daripada hakisan (Siddique et al. 2011).

Hamim (2007) berpendapat bahawa penggunaan simen dan ditambah sedikit dengan wasap silika adalah salah satu alternatif yang lebih baik untuk meningkatkan mutu dan kekuatan turapan dalam proses kitar semula sejuk setempat. Kajian yang telah dilakukan oleh Yener dan Hinislioğlu (2011) pula menunjukkan bahawa penggunaan wasap silika sebagai bahan tambah akan meningkatkan sedikit kekuatan lenturan untuk 28 hari bagi campuran turapan konkrit dan sebaliknya berlaku apabila menggunakan abu terbang. Campuran turapan konkrit menjadi lebih stabil jika kedua-dua bahan tambahan tersebut digabungkan dalam satu campuran. Kajian ini juga menunjukkan bahawa penggunaan wasap silika telah mengurangkan penyerapan cecair melalui liang-liang sedutan dalam campuran turapan konkrit tersebut dan ia mempunyai kebolehrintangan yang baik terhadap proses penggelupasan. Al-Hdabi et al. (2013) telah membuktikan penggunaan wasap silika sebagai bahan tambah dalam campuran asfalt sejuk yang mengandungi abu terbang boleh meningkatkan kekuatan awalan, kekuatan jangka panjang dan juga kebolehtahanan campuran asfalt sejuk tersebut.

\section{ABU SEKAM PADI}

Asia Tenggara adalah pengeluar 90\% padi dunia. Sekam padi mempunyai kandungan organik meruap yang tinggi seperti bahan biojisim yang lain. Sekam padi juga telah dikenalpasti berpotensi menjadi sumber tenaga. Kandungan
$20 \%$ abu mengandungi lebih daripada $95 \%$ silika amorfus menyebabkan abu sekam padi menjadi daya tarikan dari sudut ekonomi. Sekam padi terhasil daripada proses pengilangan padi dan ia adalah sisa utama yang dihasilkan daripada industri pertanian tersebut. Ia juga banyak dan mudah didapati (Balakrishnan 2006). Sifat pozzolana abu sekam padi bergantung kepada kandungan silika, fasa penghabluran silika dan saiz serta luas permukaan partikel abu sekam padi tersebut. Abu sekam padi yang mempunyai kandungan silika amorfus dan luas permukaan yang besar dihasilkan daripada pembakaran sekam padi pada suhu terkawal dengan menggunakan insinerator atau relau serta kaedah pengisaran yang sesuai untuk menghasilkan abu sekam padi yang bermutu tinggi (Zain et al. 2010).

Di dalam kajian ini, relau pembakaran yang digunakan adalah relau yang terdapat di Makmal Jabatan Kejuruteraan Awam dan Struktur, Universiti Kebangsaan Malaysia. Ia merupakan relau yang terubahsuai hasil daripada beberapa relau lain yang pernah digunakan oleh Loo di Asian Institute of Technology (AIT), Bangkok dan Ramli di Universiti Sains Malaysia (Ahmad 2007).

Gouhari et al. (2010) telah menunjukkan bahawa penambahan abu sekam padi dalam campuran turapan bagi lapisan subgred boleh membaiki kekuatan lapisan tersebut daripada segi nilai nisbah galas California dan kekuatan mampatan tak terkurung. Yaw (2011) telah membuktikan bahawa $2.22 \%$ merupakan peratus optimum abu sekam padi sebagai bahan tambah kepada campuran asfalt konkrit kerana memberikan nilai modulus kebingkasan dan kekukuhan rayapan yang paling tinggi. Osinubi et al. (2012) pula telah membuktikan bahawa turapan asfalt terpakai yang digunakan sebagai lapisan subtapak dan tapak bagi turapan boleh lentur boleh menjadi bahan yang lebih baik apabila abu sekam padi ditambah ke dalam campuran tersebut. Kajian yang dilakukan oleh Koteswara et al. (2012) telah menunjukkan bahawa penggunaan abu sekam padi semata-mata atau dicampur dengan bahan seperti kalium klorida, kapur, gipsum dan sebagainya mempunyai potensi yang baik untuk menstabilkan lapisan subgred yang luas. Penggunaan abu sekam padi merupakan satu alternatif untuk mengurangkan kos pembinaan jalan raya di kawasan luar bandar bagi negara membangun.

\section{BATU KAPUR}

Batu kapur ialah batuan yang terhasil daripada mineral semulajadi iaitu kalsium karbonat sebagai mineral utama. Sebahagian kalsium karbonat mungkin bertukar kepada dolomit dan digantikan dengan magnesium karbonat sebagai komponen kedua (sehingga 46\% mengikut berat). Kebanyakan batu kapur adalah tulen dengan jumlah bendasing (non-carbonate) kurang daripada $5 \%$. Batu kapur dijumpai dengan pelbagai bentuk dan ia diklasifikasikan mengikut asal-usul, komposisi kimia, struktur dan pembentukan geologi. Ia ditemui dengan banyak di seluruh dunia dan dijadikan sebagai bahan mentah dalam kebanyakan industri (Oates 1998). 
Batu kapur digunakan dalam campuran asfalt panas sebagai agen anti-penanggalan antara agregat. Selain itu terdapat beberapa kelebihan lain penggunaan batu kapur dalam campuran campuran asfalt panas iaitu: 1) batu kapur bertindak sebagai bahan pengisi bagi meningkatkan kekuatan asfalt pengikat dan campuran asfalt panas bagi mengurangkan masalah kegagalan pada suhu tinggi, 2) batu kapur akan meningkatkan rintangan terhadap keliatan patah pada suhu rendah, 3) batu kapur berupaya mengubah kinetik pengoksidaan dan bertindak balas dengan proses pengoksidaan tersebut bagi mengurangkan kesan buruk dan 4) batu kapur juga akan mengubah sifat plastik bagi tanah liat untuk meningkatkan kepekaan terhadapat kelembapan dan ketahanan (Little et al. 2006).

Almansah (2007) telah menunjukkan batu kapur berpotensi dijadikan sebagai bahan penstabil dalam kitar semula sejuk setempat. Puppala et al. (2012) pula telah membuktikan bahawa penggunaan batu kapur atau simen dan atau agregat muda sebagai bahan tambah kepada turapan asfalt terpakai boleh meningkatkan prestasi turapan asfalt terpakai tersebut sebagai lapisas asas turapan. Kajian yang dilakukan oleh Saghafi et al. (2012) menunjukkan bahawa penambahan batu kapur dan abu bahan api terhancur ke dalam bahan untuk lapisan asas turapan boleh meningkatkan kestabilan lapisan tersebut.

\section{KAEDAH UJIKAJI}

Aktiviti penyiasatan tapak adalah aktiviti yang perlu dilakukan untuk menentukan jenis kerosakan yang berlaku dan menentukan kaedah kitar semula yang sesuai untuk membaiki turapan. Ia melibatkan proses penggerudian lapisan turapan jalan raya untuk mendapatkan bahan turapan yang akan dikitar semula. Bahan turapan kemudiannya dihancur dan diayak untuk mengetahui kandungan asfalt dan agregat yang terdapat dalam campuran turapan. Kandungan lembapan optimum bahan turapan ditentukan melalui Ujikaji Pemadatan. Hanya 75\% turapan asfalt sedia ada dan $25 \%$ batuan hancur yang digunakan untuk mereka bentuk campuran turapan jalan raya.

Terdapat dua jenis sampel yang disediakan iaitu sampel piawai dan sampel ujikaji. Sampel piawai menggunakan $1.5 \%$ simen dan sampel ujikaji menggunakan 1, 3, 5, 7 dan $9 \%$ untuk ketiga-tiga bahan penstabil tersebut. Reka bentuk campuran dilakukan ke atas bahan-bahan dengan menambah air mengikut nilai kandungan lembapan optimum yang diperolehi dan menambah bahan penstabil. Kaedah reka bentuk campuran dengan menggunakan kaedah tukul penggetar dan Marshall digunakan untuk memadatkan campuran tanpa menggunakan haba.

Terdapat lima ujikaji yang dilakukan ke atas sampelsampel tersebut untuk mengetahui keputusan ujikaji dan membandingkannya dengan spesifikasi yang telah ditetapkan. Kaedah tukul penggetar digunakan untuk merekabentuk sampel untuk Ujikaji Pemadatan dan Ujikaji Mampatan Tak Terkurung manakala kaedah Marshall yang biasa digunakan oleh JKR dipraktikkan dalam mereka bentuk sampel Ujikaji Kestabilan dan Aliran Marshall,
Ujikaji Modulus Kekuatan Tegangan Tak Terus dan Ujikaji Rayapan Statik tanpa menggunakan haba dalam proses campuran bahan.

UJIKAJI PEMADATAN (KAEDAH TUKUL PENGGETAR)

Ujikaji Pemadatan menggunakan kaedah tukul penggetar perlu dilakukan sebelum mereka bentuk campuran untuk menentukan kandungan lembapan optimum yang menghasilkan keadaan zarah-zarah sampel yang terpadat dengan ketumpatan kering yang maksimum. Kaedah ini menggunakan mesin tukul penggetar yang digunakan untuk menghentam sampel. Air yang ditambah kepada sampel yang mempunyai kandungan lembapan yang optimum bertindak sebagai pelincir di antara zarah-zarah. Apabila air ditambah secara berlebihan, kesan pelincirannya kepada sampel turut bertambah tetapi bertentangan dengan kemampuan sampel untuk menerima lembapan yang akan menyebabkan lompang-lompang bertambah.

Daripada ujikaji yang dilakukan, ketumpatan kering $\left(P_{d}\right)$ boleh dikira menggunakan persamaan:

$$
P_{d}=\frac{100 p}{100+w}
$$

di mana $p=\left(m_{2}-m_{1}\right) /(18.15 h), m_{1}=$ berat acuan + plak tapak, $m_{2}=$ berat acuan + plat tapak + tanah lembap dan $w$ adalah kandungan lembapan. Graf kandungan lembapan melawan ketumpatan kering diplot untuk mendapatkan kandungan lembapan yang optimum seperti yang ditunjukkan dalam Rajah 1.

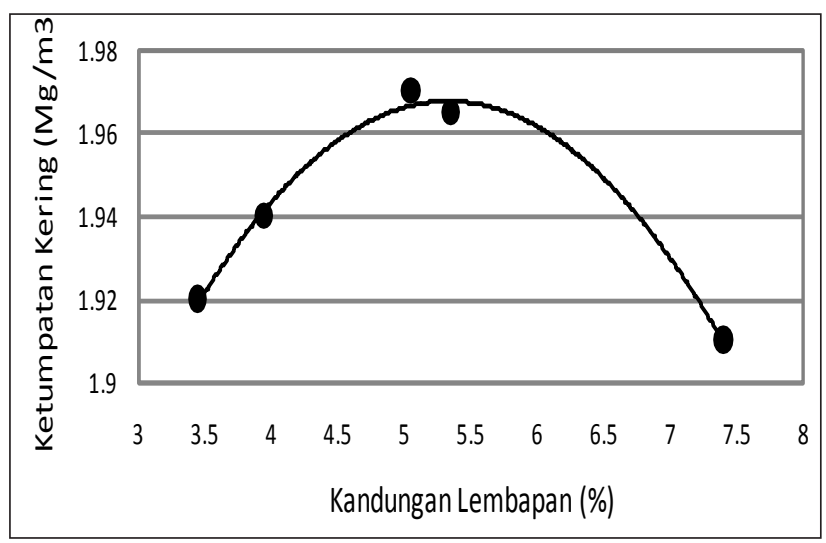

RAJAH 1. Graf ketumpatan kering melawan kandungan lembapan bagi sampel

UJIKAJI KESTABILAN DAN ALIRAN MARSHALL

Ujikaji ini dilakukan untuk menentukan kestabilan dan aliran dalam campuran berasfalt. Sampel direndam terlebih dahulu di dalam takungan air pada suhu $60^{\circ} \mathrm{C}$ untuk tempoh 30 minit sebelum ujian dijalankan. Mesin Ujikaji Kestabilan dan Aliran Marshall digunakan untuk ujikaji ini dengan meletakkan sampel di antara kepala alat penguji dan dipasang pada alat pembeban. Beban tetap iaitu $50.8 \mathrm{~mm} /$ 
min pada paksi diameter dikenakan ke atas sampel sehingga bacaan beban maksimum diperolehi dan pengurangan beban ditunjukkan pada dial beban. Beban maksimum yang mampu ditanggung oleh sampel merupakan nilai kestabilan dan bacaan pada meter aliran adalah nilai aliran yang dikehendaki. Ujikaji ini adalah berdasarkan kepada ASTM D 1559-89 (ASTM 1992). Daripada ujikaji ini, graf kestabilan Marshall melawan peratus bahan penstabil dan graf aliran melawan peratus bahan penstabil diplot seperti yang ditunjukkan dalam Rajah 2 dan Rajah 3 masingmasing.

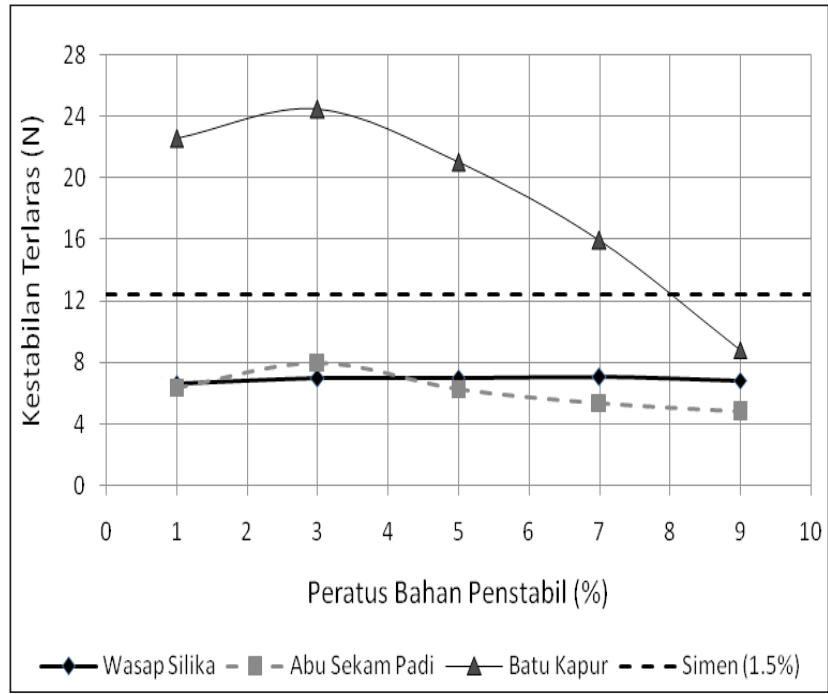

RAJAH 2. Graf kestabilan terlaras melawan peratus bahan penstabil

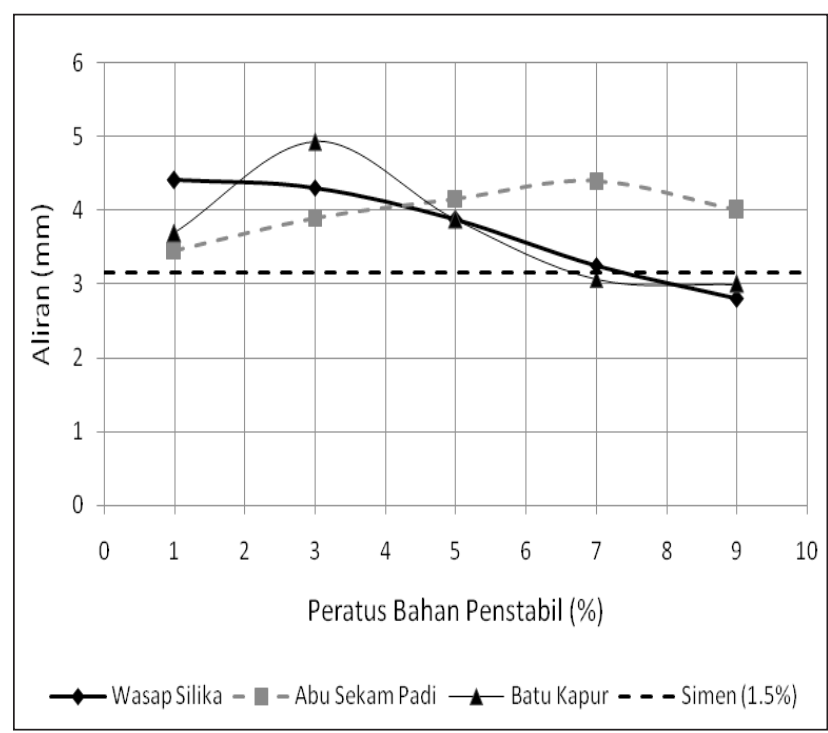

RAJAH 3. Graf aliran melawan peratus bahan penstabil

\section{UJIKAJI MAMPATAN TAK TERKURUNG}

Ujikaji ini dilakukan untuk mengukur kekuatan mampatan dalam campuran konkrit berasfalt yang stabil. Prosedur ujikaji adalah lebih kurang sama dengan prosedur ujikaji mampatan yang dilakukan ke atas bancuhan konkrit. Keputusan yang diperolehi dirujuk berdasarkan spesifikasi yang telah ditetapkan oleh American Association of State Highway and Transportation Officials (AASHTO) dalam buku piawaian yang telah dikeluarkan oleh Road Engineering Association Of Malaysia (REAM 2005).

Terdapat sedikit perbezaan dalam proses penyediaan sampel. Campuran direka bentuk dalam acuan yang lebih besar iaitu enam inci diameter. Proses pemadatan dilakukan pada tiga lapisan campuran dengan menggunakan penukul bergetar selama satu minit. Kemudian, sampel dibiarkan selama 24 jam pada suhu bilik sebelum dibuka acuannya. Sampel yang disediakan perlu diambil bacaan ketinggian dan berat sampel. Ini adalah untuk mendapatkan nilai ketumpatan pukal bagi setiap sampel sebelum sampel dibiarkan pada suhu bilik selama tujuh hari sebelum ujikaji dijalankan.

Formula yang digunakan untuk mencari kekuatan mampatan sampel ialah:

$$
\sigma_{c}=\frac{F}{A_{5} \times 10^{3}}
$$

Di mana $\sigma_{c}=$ kekuatan mampatan sampel (MPa), $F=$ beban maksimum $(\mathrm{kN})$ dan $A_{s}=$ luas permukaan sampel $\left(\mathrm{mm}^{3}\right)$. Graf nilai kekuatan mampatan yang dapat ditanggung oleh sampel melawan nilai peratus bahan penstabil diplot seperti yang ditunjukkan dalam Rajah 4.

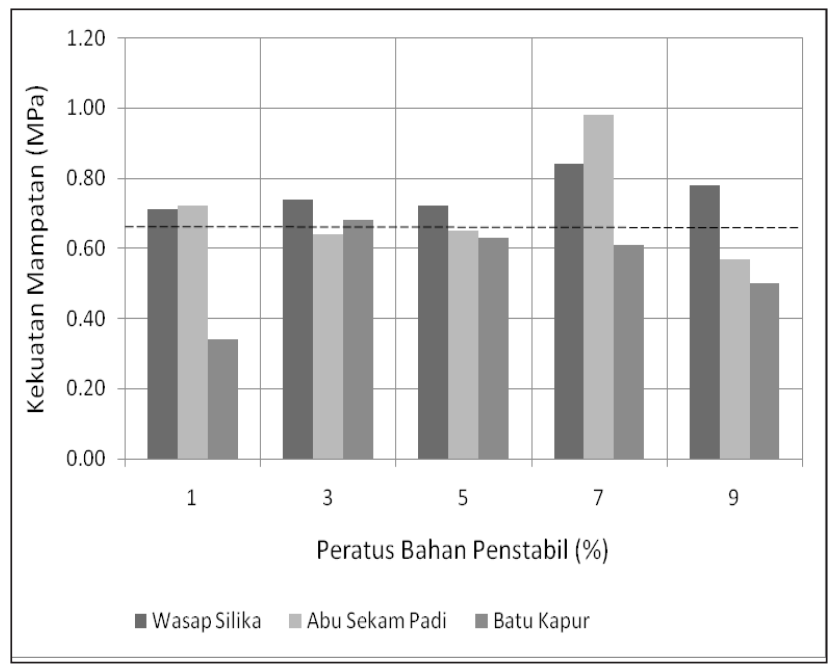

RAJAH 4. Graf kekuatan mampatan melawan peratus bahan penstabil 
UJIKAJI MODULUS KEKUATAN TEGANGAN TAK TERUS

Ujikaji Modulus Kekuatan Tegangan Tak Terus dilakukan dengan menggunakan alat Universal Testing Machine (UTM). Ujikaji ini digunakan untuk mengukur jumlah modulus kebingkasan yang boleh dikenakan pada sampel. Apabila alat penguji telah tersedia, sampel itu dimasukkan ke dalam bingkai dan skru penyepit dilaraskan dan diketatkan supaya sampel berada di tengah-tengah. Alat linear variable differential transducers (LVDT) perlu dilaraskan untuk mendapatkan bacaan aras di bahagian tengah sampel sebelum ujikaji dimulakan. Beban tetap iaitu $250 \mathrm{~N}$ dikenakan ke atas sampel pada paksi diameter dalam lima kiraan nadi dengan tempoh ulangan nadi sebanyak 3000 ms dan lebar nadi 100 ms. Segala pengiraan dilakukan oleh komputer melalui data yang dimasukkan seperti ketinggian dan diameter sampel serta beban yang telah dikenakan ke atas sampel. Keputusan ujikaji memberikan nilai jumlah modulus kebingkasan pada setiap sampel.

\section{UJIKAJI RAYAPAN STATIK}

Ujikaji Rayapan Statik juga dilakukan dengan menggunakan mesin UTM. Tujuan Ujikaji Rayapan Statik dilakukan adalah untuk menentukan jumlah terikan, pesongan, pematuhan rayapan dan kekukuhan rayapan. Prosedur ujikaji adalah sama seperti Ujikaji Modulus Kekuatan Tegangan Tak Terus tetapi beban tetap sebanyak $425 \mathrm{kPa}$ dikenakan ke atas sampel pada paksi menegak selama satu jam. Segala pengiraan dilakukan oleh komputer melalui data yang dimasukkan seperti ketinggian dan diameter sampel serta beban yang telah dikenakan ke atas sampel. Keputusan ujikaji memberikan nilai keputusan seperti jumlah terikan, pesongan, pematuhan rayapan dan kekukuhan rayapan.

\section{KEPUTUSAN DAN PERBINCANGAN}

Selepas ujikaji dijalankan, segala keputusan ujikaji dirumus dan dianalisis untuk melihat sejauh mana keberkesanan penggunaan ketiga-tiga bahan penstabil ini dalam campuran asfalt sejuk. Perbandingan keputusan ujikaji juga dilakukan untuk ketiga-tiga bahan penstabil dengan sampel piawai iaitu menggunakan simen sebanyak $1.5 \%$. Graf-graf yang diplot daripada keputusan ujikajiujikaji menerangkan tentang perbandingan keberkesanan penggunaan simen, wasap silika, sekam padi dan batu kapur sebagai bahan penstabil dalam kaedah kitar semula sejuk setempat. Secara ringkasnya, bahan-bahan yang digunakan, peratus bahan mengikut berat sampel dan jenis sampel yang direka bentuk adalah seperti dalam Jadual 4 .

JADUAL 4. Senarai dan peratus bahan untuk rekabentuk sampel

\begin{tabular}{lc}
\hline Bahan & Peratus Bahan \\
\hline Bahan Asas & 75 \\
- Turapan asfalt sedia ada & 25 \\
- Batuan hancur & \\
Pelembap Tanah & 5.05 \\
- Air & \\
Bahan Penstabil & 1.5 \\
- Simen & $1,3,5,7,9$ \\
- Wasap silika, Abu sekam padi, & \\
$\quad$ batu kapur & \\
\hline
\end{tabular}

JADUAL 5. Keputusan ujikaji rayapan statik

\begin{tabular}{lccccc}
\hline No. Ujikaji & & 1 & 2 & 3 & 4 \\
\hline Nama bahan penstabil & & Simen & Wasap Silika & Sekam Padi & Batu Kapur \\
Peratus bahan penstabil & $\%$ & 1.5 & 7.0 & 7.0 & 3.0 \\
Jumlah terikan & $\mu €$ & 5409 & 19847 & 15873 & 19890 \\
Pesongan (Deformation) & $\mathrm{mm}$ & 0.5409 & 1.9847 & 1.5873 & 1.9890 \\
Pematuhan rayapan (Creep & $1 / \mathrm{MPa}$ & 0.01289 & 0.04705 & 0.03776 & 0.04749 \\
Compliance) & & & & & \\
Kekukuhan rayapan (Creep & $\mathrm{kPa}$ & 0.01276 & 0.00348 & 0.00435 & 0.00347 \\
$\begin{array}{l}\text { Stiffness), } \\
\text { 69 kPa }\end{array}$ & & & & & \\
Jumlah terikan & & & & & \\
\hline
\end{tabular}


UJIKAJI PEMADATAN (KAEDAH TUKUL PENGGETAR)

Maklumat tentang kandungan lembapan suatu bahan penting untuk diketahui kerana ia akan menunjukkan peratus kandungan air yang akan digunakan dalam penyediaan sampel yang berikutnya. Daripada keputusan ujikaji didapati nilai kandungan lembapan optimum sampel ialah 5.5\% dengan nilai ketumpatan kering maksimum sebanyak $1.965 \mathrm{Mg} / \mathrm{m}^{3}$, seperti yang ditunjukkan dalam Rajah 1. Keputusan yang diperolehi ini menunjukkan bahawa peratus air yang akan digunakan untuk membancuh sampel ialah 5.5\% daripada jumlah berat bahan dan berat bahan penstabil.

\section{UJIKAJI KESTABILAN DAN ALIRAN MARSHALL}

Nilai kestabilan bermaksud penentuan beban maksimum yang dapat ditanggung oleh sampel sebelum gagal. Rajah 2 menunjukkan perbandingan yang dibuat untuk nilai kestabilan bagi ketiga-tiga bahan penstabil. Daripada rajah tersebut didapati batu kapur mempunyai kestabilan yang paling tinggi manakala wasap silika dan abu sekam padi mempunyai nilai purata kestabilan yang hampir sama dan lebih rendah daripada batu kapur dan simen. Batu kapur mempunyai nilai kestabilan yang paling tinggi iaitu 24.48 $\mathrm{kN}$ pada kandungannya sebanyak $3 \%$ dan diikuti oleh simen (1.5\%) yang mempunyai nilai kestabilan setinggi $12.38 \mathrm{kN}$. Kemudian diikuti oleh abu sekam padi yang mempunyai nilai kestabilan setinggi $8.00 \mathrm{kN}$ pada kandungannya sebanyak 3\%. Wasap silika mempunyai nilai kestabilan yang paling rendah jika dibandingkan dengan bahan penstabil yang lain iaitu $7.06 \mathrm{kN}$ pada kandungannya sebanyak 7\%. Ini menunjukkan batu kapur lebih stabil untuk menanggung beban maksimum berbanding simen dan bahan penstabil yang lain. Perkadaran bagi graf untuk ketiga-tiga bahan penstabil menunjukkan nilai kestabilan akan mencapai satu tahap yang optimum dan akan berkurang dengan pertambahan bahan penstabil.

Rajah 3 pula menunjukkan perbandingan yang dibuat untuk nilai aliran bagi ketiga-tiga bahan penstabil. Aliran dalam sampel menunjukkan perubahan ubah bentuk yang berlaku kepada sampel bermula daripada sampel tidak dikenakan beban sehingga sampel mengalami beban maksimum. Wasap silika mempunyai nilai aliran yang paling rendah iaitu $2.80 \mathrm{~mm}$ dan diikuti oleh batu kapur yang mempunyai nilai aliran sebanyak $3.00 \mathrm{~mm}$ pada peratus kandungan yang sama iaitu sebanyak $9 \%$. Manakala nilai aliran bagi sampel piawai (simen) pula ialah $3.15 \mathrm{~mm}$. Abu sekam padi pula mempunyai nilai aliran yang paling tinggi iaitu $3.46 \mathrm{~mm}$ pada peratus kandungannya sebanyak $1 \%$. Ini menunjukkan bahawa campuran menggunakan wasap silika mengalami ubah bentuk yang paling sedikit kerana mempunyai kebolehaliran yang rendah dan mampu menghalang air permukaan daripada menyerap masuk ke dalam lapisan tanah.

Hasil keputusan ujikaji kestabilan dan aliran Marshall ini didapati tidak konsisten untuk wasap silika, abu sekam padi dan batu kapur. Oleh yang demikian, hanya keputusan ujikaji mampatan tak terkurung, ujikaji modulus kekuatan tegangan tak terus dan ujikaji rayapan statik sahaja diambilkira untuk menentukan nilai peratusan optimum bagi setiap bahan penstabil yang dikaji.

UJIKAJI MAMPATAN TAK TERKURUNG

Ujikaji mampatan tak terkurung dilakukan bertujuan untuk menentukan nilai kekuatan bagi suatu sampel yang diuji terhadap beban maksimum yang dikenakan. Daripada Rajah 4, nilai kekuatan mampatan yang paling tinggi untuk abu sekam padi dan wasap silika ialah $0.97 \mathrm{MPa}$ dan 0.84 MPa masing-masing pada kandungan bahan penstabilnya sebanyak 7\%. Manakala batu kapur pula mempunyai kekuatan mampatan yang paling tinggi iaitu $0.66 \mathrm{MPa}$ pada kandungan batu kapur sebanyak 3\% dan kekuatan mampatan batu kapur pada 7\% hanya sebanyak $0.59 \mathrm{MPa}$ sahaja. Ini menunjukkan bahawa turapan kitar semula bancuhan sejuk yang menggunakan abu sekam padi sebagai bahan penstabil mempunyai keupayaan untuk menanggung beban yang lebih tinggi berbanding dengan bahan-bahan penstabil yang lain iaitu wasap silika dan batu kapur.

Paten keputusan ujikaji mampatan tak terkurung untuk ketiga-tiga bahan penstabil menunjukkan bahawa kekuatan mampatan akan mencapai tahap optimum dan akan berkurang dengan pertambahan bahan penstabil. Paten keputusan ujikaji ini boleh diterima kerana ia menyamai paten keputusan ujikaji mampatan tak terkurung yang dilakukan oleh Koteswara et al. (2012) ke atas abu sekam padi sebagai bahan tambah dengan peratus $0,4,8,12$ dan $16 \%$ kepada campuran lapisan subgred yang luas walaupun berbeza spesifikasi yang digunakan.

Kekuatan mampatan bagi sampel piawai iaitu menggunakan simen sebagai bahan penstabil ialah $0.65 \mathrm{MPa}$ pada kandungan simen sebanyak 1.5\%. Nilai yang diperolehi adalah menepati spesifikasi yang telah ditetapkan oleh AASHTO. Walaupun dalam spesifikasi hanya dinyatakan purata kekuatan mampatan antara 2-5 $\mathrm{MPa}$ untuk kandungan maksimum simen sebanyak 5\%. Akan tetapi, dengan interpolasi didapati nilai untuk kekuatan mampatan bagi kandungan simen sebanyak 1.5\% ialah antara $0.6-1.5 \mathrm{MPa}$.

\section{UJIKAJI MODULUS KEKUATAN TEGANGAN TAK TERUS}

Ujikaji Modulus Kekuatan Tegangan Tak Terus digunakan untuk mengukur jumlah modulus kebingkasan yang boleh dikenakan pada sampel di mana ia berkaitan dengan keretakan pada sampel. Ujikaji ini dilakukan bertujuan untuk mengukur ketegangan yang berlaku pada sampel. Semakin tinggi nilai modulus kebingkasan, maka semakin tinggi keupayaan sampel itu untuk menampung beban yang dikenakan ke atasnya. Nilai modulus kebingkasan yang diperolehi daripada ujikaji ini digunakan untuk mereka bentuk ketebalan asfalt yang optimum. Oleh itu, keberkesanan prosedur mereka bentuk ketebalan asfalt adalah berhubung terus dengan ketepatan dalam 
pengukuran modulus kebingkasan bagi sesuatu campuran asfalt tersebut. Modulus kebingkasan juga digunakan untuk menilai penanggalan agregat, sifat kelesuan dan keretakan suhu rendah campuran asfalt.

Berdasarkan kepada keputusan ujikaji seperti yang ditunjukkan di dalam Rajah 5, nilai modulus kebingkasan untuk sampel piawai iaitu pada kandungan simen sebanyak $1.5 \%$ adalah 682 MPa. Nilai modulus kebingkasan yang paling tinggi untuk wasap silika ialah $1166 \mathrm{MPa}$ pada kandungannya sebanyak 7\%, $1501 \mathrm{MPa}$ untuk abu sekam padi pada kandungannya sebanyak 7\% dan $1256 \mathrm{MPa}$ untuk batu kapur pada kandungannya sebanyak 3\%. Oleh itu, didapati abu sekam padi mempunyai nilai modulus kebingkasan yang paling tinggi jika dibandingkan dengan ketiga-tiga bahan penstabil. Perbandingan ketiga-tiga sampel dengan sampel piawai pula mendapati nilai modulus kebingkasan yang optimum untuk ketiga-tiga sampel tersebut melepasi nilai modulus kebingkasan untuk sampel piawai pada kandungan bahan penstabil yang berbeza-beza.

Keputusan ujikaji untuk ketiga-tiga bahan penstabil menunjukkan sampel berupaya menanggung beban maksimum pada peratus optimum tertentu dan kemudiannya keupayaan tersebut berkurangan dengan pertambahan peratus bahan penstabil. Paten keputusan ujikaji ini menyamai paten yang diperolehi daripada ujikaji modulus kekuatan tegangan tak terus yang dilakukan oleh Yaw (2011) ke atas campuran asfalt konkrit yang mengandungi abu sekam sebagai bahan tambah. Akan tetapi, setiap bahan penstabil mempunyai peratus yang tertentu untuk mendapatkan nilai modulus kebingkasan yang optimum bagi campuran yang direka bentuk kerana bahan penstabil tersebut mempunyai sifat fizikal dan mekanikal yang berlainan.

\section{UJIKAJI RAYAPAN STATIK}

Ujikaji rayapan dilakukan untuk mengukur ubah bentuk kekal sampel yang diuji. Nilai ubah bentuk ini menunjukkan potensi kegagalan yang disebabkan oleh lekukan bekas tayar kenderaan. Semakin tinggi nilai modulus rayapan, rintangan turapan untuk mengalami lekukan bekas tayar kenderaan adalah semakin tinggi. Hanya satu sampel ujikaji daripada setiap jenis bahan penstabil yang mempunyai nilai kekuatan mampatan dan nilai modulus kebingkasan yang paling optimum yang digunakan dalam ujikaji ini. Memadai hanya melakukan ujikaji ini ke atas sampel yang paling baik. Peratus 7\% bahan penstabil digunakan untuk wasap silika dan sekam padi manakala peratus 3\% digunakan untuk batu kapur.

Jadual 5 menunjukkan keputusan ujikaji rayapan statik untuk simen piawai dan sampel ujikaji. Sampel piawai iaitu simen mempunyai kerintangan terhadap rayapan yang jauh lebih baik jika dibandingkan dengan sampel ujikaji yang lain kerana mempunyai nilai pesongan, terikan dan pematuhan rayapan yang rendah dan kekukuhan rayapan yang tinggi. Ini menunjukkan bahawa campuran asfalt dengan simen sukar untuk mengalami lekukan bekas tayar kenderaan berbanding dengan campuran bahan penstabil yang lain. Perbandingan antara ketiga-tiga bahan penstabil pula menunjukkan abu sekam padi mempunyai kerintangan terhadap rayapan yang lebih baik kerana mempunyai kekukuhan rayapan yang paling tinggi diikuti dengan wasap silika dan kemudian batu kapur.

\section{KESIMPULAN}

Hasil kajian secara umumnya menunjukkan bahawa ketigatiga bahan penstabil yang digunakan tidak menunjukkan sifat yang konsisten. Ini kerana setiap bahan mempunyai kelebihan masing-masing dalam menentukan kekuatan turapan. Akan tetapi abu sekam padi pada peratusan kandungannya sebanyak $7 \%$ didapati mempunyai potensi yang baik untuk menyaingi simen $(1.5 \%)$ sebagai bahan penstabil dalam kitar semula sejuk setempat kerana mempunyai kekuatan dan daya menahan beban yang lebih tinggi serta kerintangan terhadap rayapan yang lebih baik berbanding dengan wasap silika dan batu kapur. Keputusan ujikaji juga mendapati kandungan optimum bagi wasap silika dan batu kapur ialah sebanyak 7\% dan 3\% perlu untuk menghasilkan campuran kitar semula asfalt sejuk yang baik. Kaedah kitar semula sejuk setempat juga didapati sesuai diaplikasikan bagi kerja penyelenggaraan jalan raya kerana ia menjimatkan kos, mengurangkan pembaziran, mesra alam dan memulihara turapan sedia ada.

RUJUKAN

Ahmad, R. 2007. Kaedah kitar semula bancuhan sejuk menggunakan abu sekam padi sebagai bahan penstabil. Tesis Sarjanamuda, Jabatan Kejuruteraan Awam dan Struktur, Universiti Kebangsaan Malaysia.

American Society for Testing and Materials (ASTM). 1992. ASTM D-1559-89. Standard Test Method for Resistance to Plastic Flow of Bituminous Mixtures Using Marshall Apparatus. Philadelpia: ASTM International.

Al-Hdabi, A., Nageim, H., Ruddock, F. \& Seton, L. 2013. Development of sustainable cold rolled surface course asphalt mixtures using waste fly ash and silica fume. Journal of Materials in Civil Engineering 10.1061/ (ASCE)MT.1943-5533.0000843.

Almansah, M. A. 2007. Kajian penggunaan batu kapur sebagai bahan penstabil dalam campuran asfalt sejuk. Tesis Sarjanamuda, Jabatan Kejuruteraan Awam dan Struktur, Universiti Kebangsaan Malaysia.

Asphalt Recycling and Reclaming Association, ARRA. 2001. Basic asphalt recycling manual.

Balakrishnan, S. 2006. Rice husk ash silica as a support material for iron and ruthenium based heterogeneous catalyst. Tesis Sarjana Sains. Universiti Sains Malaysia.

Cross, S. A., Kearney, E. R., Justus, H. G. \& Chesner, W. H. 2010. Cold-in-place recycling in New York State. Final Summary Report., Contract No. 6764F-2.

Federal Highway Administration. 1993. A study of the use of recycled paving material. FHWA-RD-93-147. 
Gouhari, B., Salbal, C., Mukherjee, S. P., Sankar, C. \& Chattopadhyay, B. C. 2010. Stabilization of subgrades of flexible pavement with admixtures. Indian Geotechnical Conference. 16-18 Disember.

Hamim, A. 2007. Kajian penggunaan wasap silika sebagai bahan penstabil dalam kitar semula sejuk setempat. Tesis Sarjanamuda, Jabatan Kejuruteraan Awam dan Struktur, Universiti Kebangsaan Malaysia.

Koteswara, R. D., Pranav, P. R. T. \& Ganja, V. 2012. A laboratory study on the efficacy of rice husk ash and potassium chloride for the stabilization of expansive soil. International Journal of Engineering Science and Technology (IJEST) 4 (1).

Kordi, N. E., Endut, I. R. \& Baharom, B. 2010. Types of damages on flexible pavement for Malaysian Federal Road. Proceeding of Malaysian Universities Transportation Research Forum and Conferences 2010 (MUTRFC2010), 21 Disember 2010, Universiti Tenaga Nasional. ISBN 978-967-5770-08-1.

Little, D. N., Epps, J. A. \& Sebaaly, P. E. 2006. The benefits of hydrated lime in hot mix asphalt. National Lime Association.

Oates, J. A. H. 1998. Lime and Limestone: Chemistry and Technology, Production and Uses. Weinheim: Wiley$\mathrm{VCH}$.

Oliver, J. E. 2002. Basic road maintenance operations. Dlm. Highways: the location, design, construction and maintenance of road pavements, disunting oleh C.A. O'Flaherty, A.M., 452-477. United Kingdom: Butterworth-Heinemann.

Osinubi, K. J., Edeh, J. E. \& Agada, J. O. 2012. Rice husk ash stabilization of reclaimed asphalt pavement. Journal of ASTM International.

Puppala, A. J., Saride, S. \& Williammee, R. 2012. Sustainable reuse of limestone quarry fines and RAP in pavement base/subbase layers. Journal of Materials in Civil Engineering 24 (4): 418-429.

Road Engineering Association of Malaysia, REAM. 2005. Specification for Cold-in Place Recycling, REAM-SP $1 / 2005$.

Saghafi, B., Al Nageim, H. \& Atherton, W. 2013. Mechanical behavior of a new base material containing high volumes of limestone waste dust, PFA and APC residues. Journal of Materials in Civil Engineering 25 (4): 450-461.

Siddique, R. \& Iqbal Khan, M. 2011. Supplementary Cementing Materials. Berlin: Springer-Verlag Berlin Heidelberg.

Syed Hamid, S. Z. 2006. Kitar semula turapan. Tesis Sarjanamuda, Jabatan Kejuruteraan Awam dan Struktur, Universiti Kebangsaan Malaysia.

Wirtgen GmbH. 2004. Wirtgen Cold Recycling Manual. Windhogen, Germany.

Yaw, P. J. 2011. Kajian penggunaan abu sekam padi sebagai bahan tambah dalam turapan jalan raya. Tesis Sarjanamuda, Jabatan Kejuruteraan Awam dan Struktur, Universiti Kebangsaan Malaysia.

Yener, E. \& Hinislioğlu, S. 2011. The effects of silica fume and fly ash on the scaling resistance and flexural strength of pavement concretes. Road Materials and Pavement Design 12 (1): 177-194.

Zain, M. F. M., Islam, M. N., Mahmud, F. \& Jamil, M. 2010. Production of rice husk ash for use in concrete as a supplementary cementitious material. Journal of Construction and Building Materials 25 (2011): 798805.

Asmah Hamim \& Nur Izzi. Md. Yusoff

Jabatan Kejuruteraan Awam dan Struktur

Fakulti Kejuruteraaan dan Alam Bina

Universiti Kebangsaan Malaysia

43600 UKM Bangi

Selangor, Malaysia

*Penulis koresponden: emel: izzi@eng.ukm.my

Serahan: 10 Oktober 2012

Terima: 19 November 2013 